\title{
CARE FROM THE BEGINNING
}

\section{Birthing Collective Origins, Interdependent Cities, and New Community Economies}

\author{
Katharine McKinnon, Stephen Healy, and Kelly Dombroski
}

\section{Introduction: Ideas to Think With}

Care is not always a concept connected with the city, but in this chapter we highlight the relations of care that are (always, already) present in urban spaces and the importance of which are becoming increasingly visible in the COVID era. Our shared survival depends on increasing our collective caring-capacity across every space-with one another, at home, at work, throughout the city and beyond. The theory of community economy we have helped to elaborate underscores the need to care for ourselves and one another in ways that affirm our shared interdependence (Gibson-Graham 2006). While this capacity for care is already in the here and now, it is often not foregrounded in our thinking of practice and is thus obscured from view. In part, what renders it insensible are a series of powerful stories we tell ourselves about human nature, the nature of economies, and the space of the city. In these stories, care is pushed to the periphery, primarily regarded as a private affair, a transactional relation, and thus, effectively, an afterthought in public life. Precisely as Jacques Derrida (1978) described more than a half century ago, these stories function as a mythic imaginary where what is present from the beginning delimits possibility.

Our aim is to offer a story that locates the origins of urban life and livelihoods in relations of care. We witness that care (has always been and is still now) present in the city in spaces of community given expression through collective action. New forms of governance and social movements over the past two decades have made it clear that cities are spaces where caring relationships can become explicit. Good examples of this are participatory civic budgeting in cities such as Porto Alegre, Kerala, and Chicago, or the commoning charter of Bologna (Bauwens et al. 2019; de Sousa Santos 1998; Pape and Lim 2019). These new forms of governance reimagine cities as spaces which we govern together for our collective benefit but also as spaces that require care from us. Infrastructures of collective care put in place by citizen-led movements demonstrate the durability of people's capacity to care in and for the city. Key examples of this include the way that Occupy New York was mobilized in 2012 to respond to the devastating consequences of Super Storm Sandy in the absence of state support (Conroy 2019) or the way that citizens in the New Zealand city of Christchurch self-organized to 
provide essential services to each other following devastating earthquakes in 2010 to 2011 (Lewis 2013). In 2020, history repeats itself as multiple forms of mutual aid and care-full distancing emerged in response to the COVID-19 crisis providing further evidence of an urban caring-capacity (Sitrin and Colectiva Sembrar 2020). We read this spontaneity as evidence that the capacity to care is there from the beginning, taking expression through a more-thancapitalist economy of reciprocity, mutual aid, and the stewardship of common resources-in short through care. Thinking with care constitutes a different starting point for imagining the form cities might take.

Efforts to actualize alternative visions of economy and urban life inevitably confront a series of common concerns: Is it really possible to do things differently, or are all efforts inevitably limited or eventually co-opted by global capital? How does meaningful change happen? What power can ordinary people possibly have to create change? And how do we persuade people with power to act differently, to care more, and to care in ways that enable equitable and sustainable urban livelihoods into the future? One of the unspoken worries behind this line of questioning is that efforts to shape cities around care are efforts that must always struggle against the dominance of neoliberal ideologies, the powers of global capitalism, and the continuing power of a politics of exclusion. Hidden in these worries is an assumption that human beings have to work hard to configure urban life around care, that in actuality the default human position is one of competition, self-interest, and the pursuit of individual success rather than the collective concerns that animate practices of care. The default has emerged in one of the more powerful human origin myths that shapes the contemporary economic scene: the idea that profit must be the prime motive of economic practice is captured in the idea of homo economicus - the mythical figure of 'rational' humanity at the heart of classical economics. This is a disheartening starting point for efforts to reshape cities around care. But we are interested in exploring what comes into view when the idea of homo economicus is abandoned and replaced with a more realistic understanding of economic subjectivity that begins with relations of care.

This chapter draws on our shared thinking on care. The foundation for this shared thinking is based in Birthing Work (McKinnon 2020), which elaborates on the work of childbirth as a collective endeavor, pursued by a network of actors who are both human and non-human. The relevance of childbirth for our thinking on care in the city may not be immediately apparent. For us, reflecting on the work and relations of care required at the beginning of life provides an opportunity to explore how the lessons of that moment might shift how we think of care for the rest of life. A (re)consideration of birth reveals how efforts to reshape urban life around care need not work so hard to displace economic imperatives that seem to encourage us to care less. Childbirth provides a different origin story, enabling us to think anew about our beginnings, about who we are and want to be (Simmonds 2016) in the cities in which we live. Our renewed origin stories can create that starting point anew, writing our interdependence into our very being, refusing the story of homo economicus. Childbirth provides a moment of ontological clarity that human experience in the urban environment is already an intimate caring connection and in community from the very beginning.

In this essay we 'think with' this moment of clarity in formulating a response to the questions posed by this volume: how to situate care at the heart of any productive and ethical engagement with urban transformations. The chapter draws on our engagements with diverse economies scholarship, an emerging interdisciplinary subfield which explores economies as a site of cultural practice, ethical concern, and political possibility. We apply diverse economies 
thinking to maternity care, using it to highlight the different actors, practices, and commitments that attend the moment of birth. Maternity care offers us a chance not just to intellectually understand the role of care and interdependence from the start but also to understand how the assumption of care and interdependence can form the basis of a new common sense. We begin with a discussion of how care and interdependence call for a shift away from homo economicus and toward a recognition of interdependence at the foundations of economic practice and human behavior.

\section{Homines Curans and the Interdependence of Origins}

At the birth of capitalism and of neoclassical economics, some very odd ideas about people and community became normalized. One of these ideas was that human instinct is driven primarily by self-interest, captured in the idea of homo economicus (HE): the ultra-rational profitmaximizing individual of classical economics and liberal ideology. HE is an economic subject present in the classical economics works of Adam Smith and John Stuart Mill, who both appealed to an instinctive drive in humans to conduct their livelihoods primarily with regard to their own interest (Mill 1836; Smith and Stigler 1986). Self-interest and competition have since been understood as the primary motivations for economic practices that enable growth and innovation. The figure of $\mathrm{HE}$ was at the center of the neoclassical economic theory from the Austrian to the Chicago school that framed neoliberalism as both an ideological project and in its variegated expression in practice for more than half a century (Harvey 2005; Peck et al. 2018). But equally important, HE is part of a powerful assertion of so-called common sense in everyday understandings of the economy (Ruccio 2008). This focus on self-interest forgets humanity's common dependence on care. Julie Stephens (2011), for example, draws our attention to the repeated work of providing care and the repeated act of accepting the care of others, which enables societies and economies to continue to function.

The task of remembering that dependency is a condition of life means also remembering a common dependence on the care of others and common origins as beings who are in connection with others. These connections are necessarily more-than-human, as Indigenous, post-humanist, and new materialist scholarship highlights (Bawaka et al. 2016; Bennett 2010; Haraway 2016; Latour 2004; Puig de la Bellacasa 2017; Thomas 2015). For ourselves, as scholars of diverse economies, the more-than-human connections are also potentially connections of active partnership and collaboration, in which more-than-human hybrid collectives are cultivated in and through practices of care (Cameron et al. 2014).

The connected human being who, with others, can construct economies around connectedness cannot be the singular HE. As an alternative to this singular HE, Joan Tronto (2017) offers the figure of homines curans — caring people plural — as the basis for a collective economic subject. The language of homines curans offers a different way of articulating human character as it already exists and already is practiced. In this it is a term that has affinities with one of the core concerns of diverse economies scholarship.

Diverse economies theory has its origins in the pioneering work of Katherine Gibson and Julie Graham (writing under the pen-name J.K. Gibson-Graham since the early 1990s). Their early efforts involved pushing back against the debilitating effects of capitalist-triumphalism, much of which was (ironically) emanating from scholars of the critical left who discussed and performed capitalism as if it were the only game in town, an all-powerful monster subsuming all other alternatives into itself (Gibson-Graham 1996, 1993). Gibson-Graham (1996: 35) 
gave the name 'capitalocentrism' to the habit of placing capitalism always in the center and non-capitalism as always the subordinate, deficient "non-existent or even unimaginable others of capitalism." In contrast, the diverse economies tradition (Gibson-Graham and Dombroski 2020) takes the deliberate step of refusing capitalocentrism and focusing instead on what we have here and now that is more than just capitalism. The methodological foundation for this work is in a deliberate effort to 'look for difference:' It is always possible to find evidence of the power of global capitalism, but what if, instead, the focus was on what exists (and persists) that is not capitalism, that is more than and other than capitalism? This practice of looking for difference informs the exploration we conduct in this chapter. In this spirit this chapter now turns to the experience of birth as a moment that underscores interdependence as the foundations of human life and as an origin story upon which the plurality of homines curans might become the assumed norm of human experience.

\section{Lessons from the Beginning of Life}

Retelling human origin stories offers one pathway for establishing the basis for a new common sense (Simmonds 2016). The first moments of new life have the potential to remind us of the foundations upon which we are all shaped and enable a foundational reconsideration of ideas about ourselves as actors in the world, the foundations of community, and the nature of care. Childbirth is brief, but the experience is deeply felt and has long-lasting effects. And the lessons of childbirth and maternity offer a fundamental challenge to the assumptions that competition and profit-seeking lie at the hearts of all human endeavors. From the very earliest stages, the embodied experience of pregnancy teaches us that childbearing can involve entering into a co-production of shared existence, a co-becoming (Dombroski 2018). Many others have explored what it means that a mother is not just a single individual anymore, but part of a mother-child dyad, but in Birthing Work Katharine McKinnon (2020) argues that pregnancy and birth entail more than a mother-child dyadthis is a 'body multiple' (Mol 2002).

Based on ethnographic interviews with mothers, midwives, and obstetricians in Australia and New Zealand, McKinnon's research offers a picture of childbirth as an assemblage, which begins in the diversity, multiplicity, and interdependence that are inescapable conditions of childbirth. ${ }^{1}$ Putting aside the conditions of conception, the pregnant woman herself is already rendered a multiple by the presence of another within - the fetus. Growing a baby and giving birth bring into play the complex work of both those bodies: hormones in flow, lungs working, hearts beating, muscles contracting, tissues stretching. And from the beginning the fetus is its own being: kicking, turning, or lodging a knee uncomfortably against the ribcage; moving into a good position for birth, or refusing to. Our origins are already, from the very beginning, collaborative: a baby, a woman, their bodies, working in tune. Add to this the complex social and cultural meanings that overdetermine motherhood, and it is possible to see that a body in childbirth is accompanied by a host of other actors, which vary depending on where that woman is situated, what her cultural background is, and how affluent she is. From this it is possible to learn that no body is ever an isolated, individual body; from the beginning 'we are not singular but multiple.'

The childbirth assemblage is also made up of actors who spread well beyond the territory of the body. The following inventory, drawn from a composite of birth stories shared during case studies, presents a typical collection of actors that might assemble around the 
average hospital birth in most urban minority world contexts. ${ }^{2}$ In the first instance, the actors who assemble to support a woman at birth will include the people who are caring for her. The mother is accompanied by her partner or a relative or friend. She has midwives and doctors and has the expectation that these medical workers will help bring her baby into the world. The medical staff bring their knowledge and expertise, gained both from formal medical training and an acquired rule of thumb. Their work is regulated by hospital policy and, in some settings, by the conditions of the indemnity insurance they are required to carry. Those insurance companies employ actuaries who assign probability and dollar values to risk, thus overlaying clinical decisions with financial significance, and as a consequence money becomes important. Emotions are also at work in the birthing space. For example, fear might be working within the doctor's limbic system to shape particular decisions. In turn, the fear that may be felt by a mother will affect her hormones, promoting the release of adrenaline and inhibiting oxytocin - the hormone that is released when we feel love and which body produces during labor. This shift in the hormonal balance is understood to in turn slow down a labor (Buckley 2011, 2015). When labor slows down, the importance of time comes to the foreground. Perhaps synthetic Oxytocin (Pitocin or Syntocinon) is introduced to help speed things up. These synthetic hormones usually create intense contractions, inhibit the body's production of natural oxytocin, and lead thus to a significant increase in pain. To relieve the pain an epidural is often recommended, bringing in an anesthetist who delivers the pain relief and the pharmaceutical companies who test and supply the drugs. The drugs administered through an epidural may distress the baby, which is detected through the Cardiotocogram (CTG) that may be monitoring the heart rate. Then perhaps there is the rush to the operating room. By this time the web of actors includes many people (mother, baby, midwife, obstetrician, anesthetist, actuary), institutions (hospital, insurance companies, actuarial companies), emotions and sensations (fear, pain, joy), technologies (CTG, epidural, scalpel), biophysical elements (hormones, limbic system). The whole is a messy and complicated gathering of human and non-human presences in the birth space: a childbirth assemblage made up of human and non-human actors that do the work of birth together.

Another way of seeing this assemblage is as a community. Our casting of assemblage as a community takes a prompt from Jean-Luc Nancy's (1991) considerations of the community as something formed in the shared mutual coming-into-being of a new life. To be in common does not mean to have, or to be aware of, a common, substance, essence, or identity "but that there is being-in-common" (ibid.: 7). Nancy provides a language that, in the context of the childbirth assemblage, enables recognition that because each actor is involved in shaping the experience (and the outcomes) of birth, the assemblage is thereby involved in a communal act, an act of collaboration. Whether it is recognized or not, whether collaboration is consciously sought out or not, all of those involved are part of a collective endeavor. Members of the collective may even be in conflict, but that does not diminish the fact that they are working together on a common concern. From the very beginnings of a child's life, that child is embedded in a broad community that has come together to see her/him safely through birth. When told in a way that highlights our interdependencies, the story of a childbirth assemblage reveals that we are already in an intimate caring connection from the beginnings of life; it reveals that community is there from the beginning. HE would have us believe that a child is thrust into a world defined by self-interested profit maximization. In contrast, the childbirth assemblage recasts the human as coming-into-being in the community. 
The inevitability of our being-in-common, and in this case of our coming-into-being-incommon, is already informing initiatives that seek to build economies around the affirmation and negotiation of our interdependencies: what Gibson-Graham (2006: 87; see also GibsonGraham et al. 2013) call "community economies." What is interesting to us is how a change of starting point can change what is understood to be the foundations of urban livelihoods, even in cases of initiatives that are not consciously enacting a community economy.

Below, we extrapolate from the lessons learned from childbirth: If we all already comeinto-being in the community how does that change perspectives on economic life? How might economic success be recast as fulfilling the mutual obligations of care? Like GibsonGraham's refusal of the capitalocentric viewpoint and methodological stance of looking for difference, we have been curious about mutual care and the in-common-ness of urban life that is always already there but is seldom seen as primary. Below, we highlight just one example drawn from the research we are engaged in. In this case we choose to focus on social enterprises that offer employment opportunities to people with disabilities. As with all social enterprises, these are commercial businesses that place a social or environmental mission at their core and re-invest their profits in pursuit of the mission that drives them. In these enterprises commercial viability is a primary concern, but when we delve a little deeper it becomes possible to see how care is also pivotal to everything the enterprise does. We suggest that there are lessons for all workplaces in the ways care might be foregrounded.

\section{Case Study from the City: Community Economy Praxis of Care in a Social Enterprise}

Work Integration Social Enterprises (WISE) have a mission oriented to providing jobs for people who could not find work otherwise. These enterprises are transitional: providing opportunities for the disadvantaged individuals with the intention that they will 'graduate' to 'real' jobs elsewhere. A study in two regional cities in Australia investigated the way WISE create not just a socially responsible enterprise and a workplace but produce well-being for those that work there (Farmer et al. 2016). In these cases, the WISE in the study focused on providing employment for people with a range of physical and psychological disabilities as 'supported workers.' The study involved four social enterprises across two regional cities in Australia - a context in which there is a perceived gap between concentrations of wealth and innovation in metropolitan centers, such as Melbourne or Sydney, and smaller regional cities. The research project was investigating how the well-being created within the WISE could address some of that regional disadvantage. In 2016, thirty percent of both city's populations were living in the most disadvantaged areas classified by Australian Social-Economic Indexes for Areas (Australian Bureau of Statistics 2018), and the enterprises themselves were located in city suburbs with higher relative disadvantage. The enterprises, Farm, Catering, and AssistAll, provide work integration for people with a disability and/or disadvantage (called here 'supported workers') in a supported work environment. CommunityCentre is not primarily a WISE but operates as a community center supporting several small social enterprises with the aim of supporting members of the local community. Both Farm and Assist All provide light manufacturing, mail-outs, assembly, cleaning, and maintenance; Catering is engaged in food preparation and production, and enterprises supported by Community Centre include a small home cleaning service, recycled clothing shop, and vegetable box delivery service. 
Interviews showed that for both the supported workers and the staff at these enterprises, there was a very real sense of well-being that came from their involvement. Staff felt satisfaction in doing something good for the community. Many supported workers felt their involvement had been transformational. For example, Carol (personal communication, October 2017), a supported worker with CommunityCentre: "It is good for your heart. It's good for all of you. Makes you think. You get home and you think geez that was a good day. That's how it's been because of it." Yet there was tension too. Employees are not well paid, and despite best intentions only one person 'graduated' to the open labor market.

In fact, most workers could really only thrive in the WISE context where they had support that most enterprises do not provide: Staff were responsive to shifting daily needs, responsive to shifting emotional states, and introduced additional support for the broader physical health of workers when it was required. Jessica, a staff member at the enterprise AssistAll, spoke, for example, about how staff needed to work with families of supported workers in providing personal care support that cross the usual boundaries between home life and working life. Jessica (personal communication, June 2017) highlighted how this extended to being "aware of some of the [menstrual] cycles for female employees" and responding to the emotional and hygiene needs that arise, "making sure that [employees] are okay in the bathroom" or reminding them to take their medication. Jessica (ibid.) characterized this attention as a necessary response to the needs of employees because, "the employees have varying, like any human being, complex personal lives and complex health issues."

Such daily attentiveness to the giving and receiving of care, however, was also seen by the enterprises to be in tension with the imperatives of commercial success. While these organizations were providing employment for people with disabilities they were also business enterprises. As William (personal communication, November 2017), also from AssistAll, said: “At the end of the day, we're all about providing employment, but at the same time we're about trying to generate money to keep the company and that going." Although care and the creation of well-being were both chief to the daily operations of the enterprises in the study, what was also clear was that the enterprise model they were working with did not provide space to properly acknowledge this, or to value it. One of the clients of CommunityCentre (personal communication, March 2018) highlighted the problem that by expecting social enterprises to "purely generate their own funds from internally generated cash" and the provision of services, the result is "a risk that by focusing purely upon the provision of services that you only get what you pay for and not all the other social goods which surround that."

The concern that focusing on what you pay for diminishes the value placed on other social goods speaks to common worries that when generating money becomes a concern, efforts to shape practice around values of care automatically take second place. Hidden in this assumption is the ghost of HE, and the idea that the default for any commercial enterprise is based on competition, self-interest, and the pursuit of individual success rather than the collective concerns that animate practices of care and the pursuit of broader social goods. Yet each WISE succeeds because it has a group of clients across the city who are choosing to put care alongside considerations of price or quality in making purchasing decisions. Furthermore, while these organizations are uncomfortably placed in charge of care provision and commercial viability, the case studies also emphasized how practices of care and connection, commercial operations, and commonwealth might be meaningfully connected. We suggest that there are many more examples in which enterprises of all kinds are obliged to place the well-being of workers at the foreground and engage in practices of care that cross the boundaries between 
the professional and the personal. Again, as Jessica from Assist All pointed out, all human beings have complex lives, all human beings must at times be the recipients of care. These organizations offer an example in which care is central to the capacity and productivity of workers, and might be considered equal to commercial success in securing the health of the enterprise and contributing to the wider community.

\section{Conclusion}

In this chapter, we have offered an alternative origin story, where the collective work of childbirth can be a source for thinking differently about care and the city. In childbirth we are already situated in connection with others-hybrid human and more-than-human. We begin already situated within community, already knowing that surviving well is about doing it together. We take our first breath already implicated within the relationships of care that being-in-community entails. Considering the collective beginnings of life is one way we might learn how to shift away from the assumed traits of rational profit-maximizing subjectivities and learn to foreground our part of collective responsibility to care that originates in how we come-into-being-in-community. As collective subjects from the start, embedded in community and associated obligations, we can foster curiosity and experimentation into effectively enacting interconnection in everyday life in the city. There is work involved in enacting city alternatives, in the form of commons, social enterprises, or the reconfiguration of capitalist enterprises around concerns for care. This work is often framed as an uphill battle against neoliberal norms, fierce competition in the global market, and the inevitability of human self-interest. These are origin myths based in accepting the truth of $\mathrm{HE}$ as the subjectivity that economic practice must draw from and foster. But it is a myth that acts against us. Paying attention instead to childbirth we can focus on the fact that we all, already, begin in community. Rather than having to fight an uphill battle to transform subjectivities into homines curans, the care work we already do in the city can be recast as a natural extension of collective origins, and the community actions that we are already entangled with.

\section{Note}

1 We recognize the pregnant persons may not identify as mothers, or with the pronoun 'she.' In our study, we did not have the privilege of engaging with nonbinary and trans folk, and our language reflects that accordingly.

2 The term 'minority world' replaces more commonly used terms of 'First World,' or 'North.' It offers recognition that the concentrations of wealth and accompanying access to technology, infrastructure, and consumerist lifestyles characterize life for a global minority who enjoy middle- and upper-class incomes. In this case, the standard of medical care that characterizes a minority world setting can be accessed by elites located in the Global South, as much as they remain inaccessible to impoverished or marginalized groups who may be located in the Global North (see Liu et al. 2020).

\section{References}

Australian Bureau of Statistics (2018) Socio-Economic Advantage and Disadvantage [Online]. Available at https://www.abs.gov.au/ausstats/abs@.nsf/Lookup/by\%20Subject/2071.0 2016 Main\%20Featu res $\sim$ Socio-Economic\%20Advantage\%20and\%20Disadvantage 123 [Accessed 10 August 2021]. 
Bauwens, M., Kostakis, V. and Pazaitis, A. (2019) Peer to Peer: The Commons Manifesto. London: University of Westminster Press.

Bawaka Country, Wright, S., Suchet-Pearson, S., Lloyd, K., Burarrwanga, L., Ganambarr, R., GanambarrStubbs, M., Ganambarr, B., Maymuru, D. and Sweeney, J. (2016) Co-becoming Bawaka: Towards a Relational Understanding of Place/Space. Progress in Human Geography 40(4): 455-475.

Bennett, J. (2010) Vibrant Matter: A Political Ecology of Things. Durham: Duke University Press.

Buckley, S.J. (2011) Undisturbed Birth. AIMS Journal 23(4) [Online]. Available at https://www.aims .org.uk/journal/item/undisturbed-birth [Accessed 25 October 2020].

Buckley, S.J. (2015) Hormonal Physiology of Childbearing: Evidence and Implications for Women, Babies, and Maternity Care. Washington, DC: Childbirth Connection Programs, National Partnership for Women \& Families.

Cameron, J., Gibson, K. and Hill, A. (2014) Cultivating Hybrid Collectives: Research Methods for Enacting Community Food Economies in Australia and the Philippines. Local Environment 19(1): 118-132.

Conroy, W. (2019) The (Im)Mobilities of Mutual Aid. ACME: An International Journal for Critical Geographies 18(4): 875-891.

de Sousa Santos, B. (1998) Participatory Budgeting in Porto Alegre: Toward a Redistributive Democracy. Politics and Society 26(4): 461-510.

Derrida, J. (1978) Writing and Difference. Chicago: University of Chicago Press.

Dombroski, K. (2018) Learning to Be Affected: Maternal Connection, Intuition and "Elimination Communication". Emotion, Space and Society 26: 72-79.

Farmer, J., De Cotta, T., McKinnon, K., Barraket, J., Munoz, S.A., Douglas, H. and Roy, M. (2016) Social Enterprise and Wellbeing in Community Life. Social Enterprise Journal 12(2): 235-254.

Gibson-Graham, J.K. (1993) Waiting for the Revolution, or How to Smash Capitalism While Working at Home in Your Spare Time. Rethinking Marxism 6(2): 10-24.

Gibson-Graham, J.K. (1996) The End of Capitalism (As We Knew It). Oxford: Blackwell.

Gibson-Graham, J.K. (2006) A Postcapitalist Politics. Minneapolis: University of Minnesota Press.

Gibson-Graham, J.K., Cameron, J. and Healy, S. (2013) Take Back the Economy: An Ethical Guide for Transforming Our Communities. Minneapolis: University of Minnesota Press.

Gibson-Graham, J.K. and Dombroski, K. (2020) Introduction to the Handbook on Diverse Economies: Inventory as Ethical Intervention. In J.K. Gibson-Graham and K. Dombroski (eds.) The Handbook of Diverse Economies. Cheltenham: Edward Elgar, pp. 1-24.

Haraway, D. (2016) Staying with the Trouble: Anthropocene, Capitalocene, Chthulucene. In J.W. Moore (ed.) Anthropocene or Capitalocene? Nature, History, and the Crisis of Capitalism. Oakland: PM Press, pp. 34-76.

Harvey, D. (2005) A Brief History of Neoliberalism. Oxford: Oxford University Press.

Latour, B. (2004) Why Has Critique Run Out of Steam? From Matters of Fact to Matters of Concern. Critical Inquiry 30(2): 225-248.

Lewis, K.V. (2013) The Power of Interaction Rituals: The Student Volunteer Army and the Christchurch Earthquakes. International Small Business Journal 31(7): 811-831.

Liu, A., Waliuzzaman, S.M., Do, H., Haryani, R. and Pem, S. (2020) Journeys of Postdevelopment Subjectivity Transformation: A Shared Narrative of Scholars From the Majority World. In J.K. Gibson-Graham and K. Dombroski (eds.) The Handbook of Diverse Economies. Cheltenham: Edward Elgar, pp. 444-452.

McKinnon, K. (2020) Birthing Work: The Collective Labour of Childbirth. New York: Palgrave MacMillan.

Mill, J.S. (1836) On the Definition of Political Economy, and on the Method of Investigation Proper to It. London and Westminster Review 4(October): 120-164.

Mol, A. (2002) The Body Multiple: Ontology in Medical Practice. Durham: Duke University Press.

Nancy, J.L. (1991) Of Being in Common. In Miami Collective (ed.) Community at Loose Ends. Minneapolis: University of Minnesota Press, pp. 1-12.

Pape, M. and Lim, C. (2019) Beyond the "Usual Suspects"? Reimagining Democracy With Participatory Budgeting in Chicago. Sociological Forum 34(4): 861-882. 
Peck, J., Brenner, N. and Theodore, N. (2018) Actually Existing Neoliberalism. In D. Cahill, M. Cooper, M. Konings and D. Primrose (eds.) The Sage Handbook of Neoliberalism. London: Sage Publications, pp. 3-15.

Puig de la Bellacasa, M. (2017) Matters of Care: Speculative Ethics in More Than Human Worlds. Minneapolis: University of Minnesota Press.

Ruccio, D.F. (ed.) (2008) Economic Representations: Academic and Everyday. New York: Routledge.

Simmonds, N. (2016) Transformative Maternities: Indigenous Stories as Resistance and Reclamation in Aotearoa New Zealand. In M. Robertson and P.K.E. Tsang (eds.) Everyday Knowledge, Education and Sustainable Futures. Singapore: Springer Singapore, pp. 71-88.

Sitrin, M. and Colectiva Sembrar (eds.) (2020) Pandemic Solidarity: Mutual Aid During the Covid-19 Crisis. London: Pluto Press.

Smith, A. and Stigler, G.J. (eds.) (1986) Selections from the Wealth of Nations. Arlington Heights: Harlan Davidson.

Stephens, J. (2011) Confronting Postmaternal Thinking: Feminism, Memory, and Care. New York: Columbia University Press.

Thomas, A. (2015) Indigenous More-Than-Humanisms: Relational Ethics With the Hurunui River in Aotearoa New Zealand. Social \& Cultural Geography 16(8): 974-990.

Tronto, J. (2017) There Is an Alternative: Homines Curans and the Limits of Neoliberalism. International Journal of Care and Caring 1(1): 27-43. 
$\because$ Taylor \& Francis Taylor \& Francis Group http://taylorandfrancis.com 